\title{
DEMOGRAPHIC COMPOSITION OF REGIONAL POPULATION REPAIR: PROBLEMS AND PROSPECTS
}

The article is about problems of reproduction of the population of Ternopil region. Substantiated demographic policy is an important factor in regulating population reproduction processes. It should have influence on the formation of the society's desired mode of reproduction of the population or preservation of changes in trends in the dynamics of population and structure of population, the pace of their changes, dynamics of birth rate, mortality, family composition, internal and external migration, qualitative characteristics of the population. It is necessary to develop and approve the Concept of Demographic Development of Society if we want to improve the current demographic situation in Ukraine and in the Ternopil region. An assessment of trends in the demographic development of the Ternopil region is presented in this article. Authors concludedthat the current demographic situation is negative after studying demographic processes in the region. The population is reduced due to natural and mechanical movements. Analyzing the current state of the development of demographic processes in the Ternopil region, it is advisable to identify trends in population changes in the future. Therefore in this article we made evaluation of the prospects of population development in the region. The article contains information about population in Ternopil region and that it will decrease in the future. Therefore, the development of effective demographic policies is necessary. It would stop the negative processes of reproduction of the population, by changing the direction of their development. It involves real and specific steps for the development of the economy, the social sphere and improve the living level of the region. Practical recommendations on the perspective and ways of improving the demographic situation in the region are developed in the article.

Keywords: reproduction of the population, demo development, demographic situation, demographic factors, demographic policy, demographic development strategy.

Problem in general and its connection with important scientific and practical tasks. The demographic situation in Ukraine and in the Ternopil region in particular attracts attention of scientists to its negative impact on social development, including the development of the labor potential of the country. The process of aging of the population increases the pressure on the ablebodied part of society and requires urgent measures by the state. The demographic crisis in Ukraine needs a scientific study in order to determine its impact on labor potential.

Research is relevant, because the study and forecasting of demographic development is an integral part of the development of concepts, programs of regional development, improvement of socio-demographic, economic situation.

Results of research and publications in which is a solution. Demonstration processes in Ukraine have been the subject of research by many scientists for many decades. Special attention is paid today to the works of scientists: M. Dolishniy, S. Zlupko, E. Libanova, O. Melnyk, S. Novikova, S. Petrova, S. Pyrozhkov, S. Pisarenko, A. Poznyak, M. Ptuha, M. Romanyuk, V. Steshenko, L. Shaulska and others. They have made a great contribution to the theory of demo development.

However, despite the wide range of investigations of modern demographic processes and aspects of labor potential development in the region, the effectiveness of state demographic policy and regulation of population reproduction processes are still not fully explored. Given this, increasing attention to economic studies of various aspects of reproduction of demographic processes.

The purpose of the article. Estimation of demographic trends and perspectives of population development in the region; development of practical recommendations on the prospects and the ways of improving the demographic situation.

The main research material. The population of the region was constantly changing under the influence of both natural and socio-economic conditions. The change in this size and the current state of the population of the region shows the demographic situation. The population has changed 
due to natural and migration movements in the region. By the end of the 1980s, natural growth was playing a decisive role in shaping population changes, while the role of migration was insignificant; from 1990 to 1993, the impact of migration processes was decisive, and since 1994 the decline in population has been conditioned as natural, so and migration decrease. Since 1994, the population of the Ternopil Region has decreased (in general, in Ukraine since 1993). Every year, region lost from 2.3 thousand people in 1995 (the smallest) to 8.6 thousand people in 2001 (the highest). On 01. 01. 2017 the number of the population of the region was 1059.2 thousand people (in Ukraine 42584.5). The decrease was not only due to the natural decrease - 1,174.4 thousand people lived in 1996 (natural decrease - -116.2 thousand people). The rate of population decline in 2016 was 4.1 per 1,000 populations.

The migration outflow of the population in the region is - -1537 people in 2016 (this indicator only shows official statistics that often do not correspond to reality, since illegal migration movements have not been taken into account). Consequently, the total decrease of the population in the region in 2016 was due to both natural and migratory contraction.

According to statistics at the beginning of 2017, the number of population decreased in 16 districts of the region. A small increase in the population is recorded only in the city of Ternopil and in the Ternopil region. Significant decrease in population is observed in Zboriv, Terebovlya, Berezhany districts.

The main factor in shaping the population is its natural reduction. It was in all districts of the region, except for the Buchach district and the city of Ternopil, where in 2016 there was a natural increase in the population. The natural reduction of the population is the result of exceeding the number of deaths over the number of births. 7070 children were born in the region during 2016 (274909 in Ukraine), and 11004 people died (428471 in Ukraine). Natural decline of the population in 2016 - 3934 persons (-153562 - in Ukraine). In the region, the infant mortality rate is high - 60 deaths under the age of 1 year (2032 in Ukraine).

The proportion of women of reproductive age (15-49 years) in the total population is one of the important factors of natural population growth. This figure amounted to about $48 \%$ in Ternopil region in 2016. The number of women of the highest childbearing activity (20-24 years old) was about $15 \%$ of the reproductive contingent.

Reducing mortality rates is a real reserve for reducing the natural population decline in the region. The intensity of mortality depends on the age population. The highest mortality rates are registered in the Pidjaytsya and Lanovets districts, where there is a high proportion of elderly people.

Unfortunately, the modern socio-economic problems of the region do not contribute to the simple reproduction of the population. As you know, ensuring simple reproduction requires that each family has at least 2.2-2.4 children.

Modern processes of forming a family in the region have the following features: the tendency to increase early marriages and high divorce rates; the institution of families for the birth of 2-3 children is not implemented; low-income families postpone the birth of the first child. Therefore for an area the average family structure is typical: father, mother, 1.2 children (narrowed reproduction of the population).

Migratory population decline affects less than a natural decrease in the formation of the total population of the region. In last years, the migration outflow of population began to decrease gradually (according to official statistics).

Low natural population growth predetermines the deformation of its age structure, reducing the natural increase of the economically active population. "Aging" of the population leads to an increase in the demographic load of the able-bodied, to some difficulties in shaping the labor potential of the region and to provide the economy with labor, is one of the worst signs of deteriorating demographic conditions for its reproduction. 


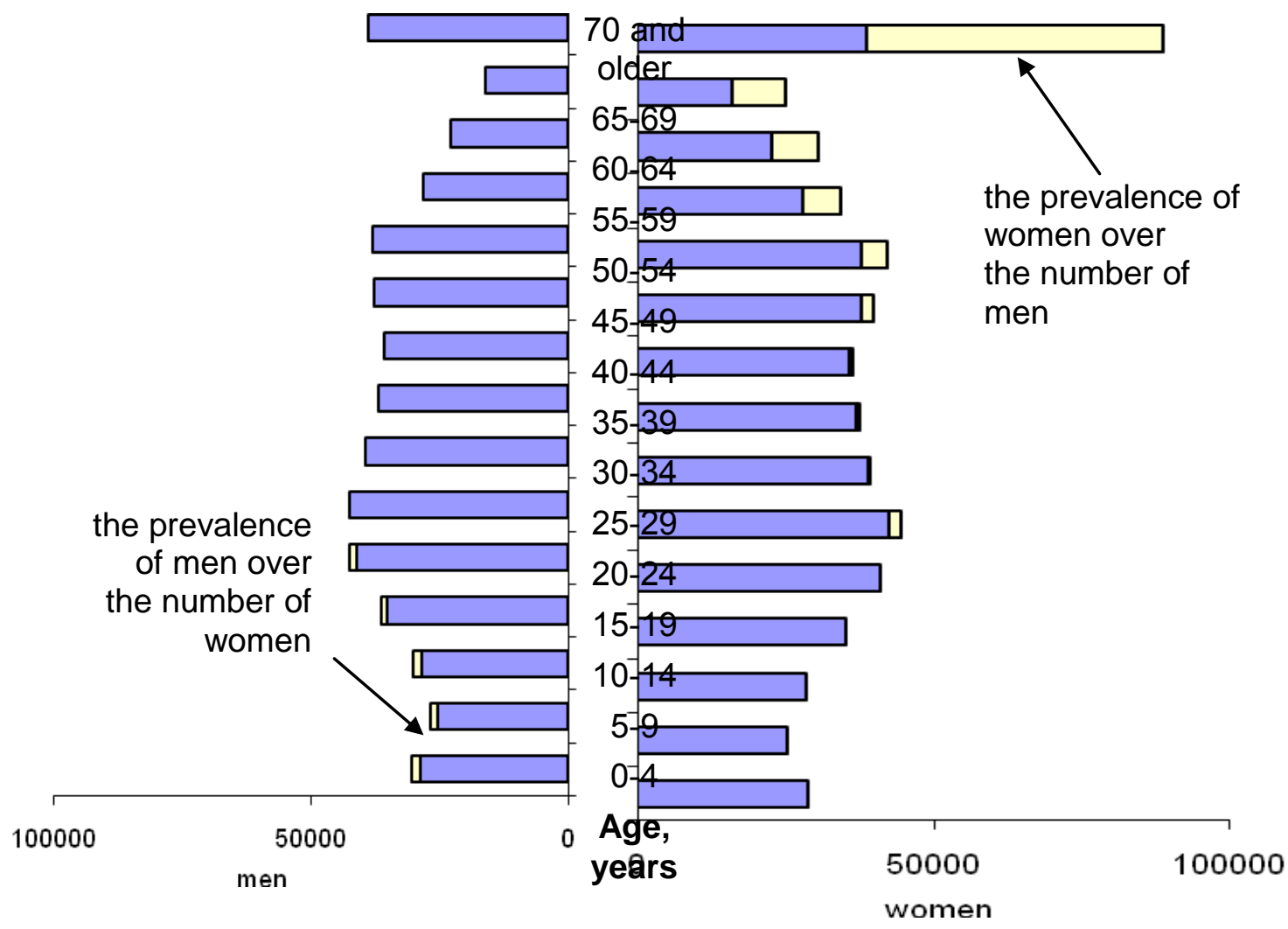

\section{Drawing 1. Distribution of permanent population by sex by age group in the Ternopil region (persons) [2]}

The largest group in the region is the group of people of working age (55.6\%), but it is decreasing. The group of people of retirement age in Ternopil region is growing. The number of children and teens (persons of working age) in the region is much smaller than that of pensioners. And it has been steadily declining in last years in connection with declining fertility rates $(15.7 \%)$.

Analyzing the current state of development of demographic processes in the Ternopil region, it is necessary to identify trends in population size in the future. But they aren 't comforting (chart 1).

Chart 1

\section{Forecast of the population of the Ternopil region}

(compiled by authors on the basis of [2])

*Data as of 01.01 .2017

\begin{tabular}{|l|c|c|c|}
\hline \multirow{2}{*}{} & \multicolumn{3}{|c|}{ Population, thousand persons } \\
\cline { 2 - 4 } & $\mathbf{2 0 1 7} *$ & $\mathbf{2 0 2 2}$ & $\mathbf{2 0 2 7}$ \\
\hline Total & 1059,2 & 1047,1 & 1028,6 \\
\hline Urban settlements & 473,0 & 476,9 & 477,9 \\
\hline Countryside & 586,2 & 570,2 & 550,7 \\
\hline
\end{tabular}

As you can see, the population of Ternopil region will decrease in the future. This decrease will occur at the expense of the rural population, which will be $9.1 \%$ less in 2027 than in 2017, and the urban population will hardly change - it will grow only $0.5 \%$.

The most problematic territories of the region, according to the population projections, are Monastic (-19.8\%), Zalishchytsky (-15.2), Podgaitse (-15.2), Borshchivsky (-10.8) and Berezhansky $(-10.7 \%)$, and the increase in population will affect only Ternopil $(+9.4 \%)$ and Buchach $(+2.5 \%)$ districts. At the same time, the number of women will decrease at a faster pace (by 6.3\%) than men (by $2.5 \%$ ).

It recognizes changes in the sex-age structure of the area. The proportion of the population 
of working age will considerably decrease and grow at the age of older than able-bodied. The population of the working age will make up only 53\% of all inhabitants, and those older the working age $-32 \%$. It will negatively affect all area of life of the region. Increasing the burden on jobseekers will cause problems in providing people with pensions and other social guarantees.

Such a forecast of the demographic situation in the Ternopil region encourages searchiag for ways to improve it. It is important to ensure an effective socio-demographic policy of the state and its separate regions.

The demographic policy of Ukraine and its regions in the present conditions should be aimed not only at stimulating the birth rate, but also in strengthening the family, raising the material well-being of the people, reducing the morbidity and mortality. However, event to manage the processes of reproduction of the population don't give fast results. The demographic behavior of people is extremely conservative, it is difficult to change.

In this case, it is expedient to apply the following measures: to increase the life expectancy of the population by improving the quality of life, reduction of premature mortality, especially in childhood, teens and people of working age; improve reproductive health of the population; to increase the duration of healthy (active) life by reducing morbidity, injury and disability; to create the preconditions for increasing the birth rate due to the gradual transition from the low-incometo middle-child type of reproductive behavior of families.

Conclusions. Ternopil region and including Ukraine have many of demographic problems. It can be argued that the demographic situation negatively affects the formation of the labor potential of the region. Natural growth remains negative, birth rate is rising, but the mortality rate remains high. The highest rates of mortality are population's working ages.

When the social and economic crisis will be overcome and the standard of living of the population will increase then the demographic situation will start to improve due to the reduction of mortality rates first of all. However, the current demographic crisis experienced by the state and its regions will have a profound effect on the demographic situation in the future. It will affect the age structure of the population, the ratio of the articles, the structure of mortality, population health, and its size, dynamics, gene pool and labor potential. There are no grounds for expecting rapid and positive changes in the increasing amount of the population and it labor potential.

\section{References}

1. Babiak H.P., Shuspanov D.G. Strategies of socio-demographic development of the region /H. P. Babiak, D. G. Shuspanov //Regional aspects of development and placement of productive forces of Ukraine: scientific journal. Whip 20. - Ternopil: Economic Thought, 2015. - P. 26-32.

2. The Main Department of Statistics in the Ternopil Region [Electronic resource]. - Access mode: http://www.te.ukrstat.gov.ua.

3. Hypotheses of perspective trends of population migration by 2050 [Electronic resource]. - Access mode: http://lib. selyam.net/docs/3400/index-39877.html?page=24.

4. Demographic forecast for Ukraine /Institute for Demography and Social Studies M.V. Ptuhi. [Electronic resource]. http://www.idss.org.ua/monografii/popforecast2014.rar.

5. State Committee of Statistics of Ukraine [Electronic resource]. - Access mode: http://ukrstat.gov.ua.

6. Kachan Ye.P., Dyakiv O.P., Faifura V.V., Shushanov D.G. Development of labor potential of Ternopil region in conditions of overcoming of demographic and economic crisis $/ Y e$. P. Kachan, O. P. Dyakiv, V. V. Faifura, D. G. Shushpanov //Regional aspects of development and placement of productive forces of Ukraine: 3b. sciences works. Whip 17. - Ternopil: Economic Thought, 2012. - P. 108-114. 